\section{SYNTHESIS BETWEEN CHINESE AND WESTERN THEATRICALITIES OF THE THREE-TIERED STAGE PLEASANT SOUND PAVILION}

\section{Sasiporn Petcharapiruch ${ }^{1}$}

\begin{abstract}
The Chinese three-tiered stage Pleasant Sound Pavilion (Chàngyin Gé 暢音閣) in the Forbidden City is the only "three-tiered stage” chóngtái sāncéng 崇臺三層 (or the “linked performance stage" lián xitái 連戲 臺) still in existence. It was an innovation of Chinese architecture that reflected the heyday of court theater during the reign of Qianlong (1736-96). This three-tiered stage mirrored the ingenuity of the Qing court theater. How a three-tiered stage like the Pleasant Sound Pavilion was brought to life is quite interesting. It was a synthesis of highly developed traditional Chinese architectural forms and innovations of Western theater, aided by advances in science in the Qing period. However, most importantly, it stemmed from the Emperor Qianlong's personal passion for Chinese theater. My goal is to analyze the genesis of this extant three-tiered stage and use it as a way to understand traditional Chinese architecture and its ingenuity in the reign of Qianlong, as well as to comprehend
\end{abstract}

\footnotetext{
${ }^{1}$ Lecturer, Department of Eastern Languages, Faculty of Arts, Chulalongkorn University
}

characteristics of court theater during this era.

Keywords: three-tiered stage; Emperor Qianlong; Sino-Euro synthesis; court theatre

\section{Introduction}

The Pleasant Sound Pavilion (Chàngyinn Gé 暢音閣) ${ }^{2}$ is the only extant three-tiered stage (chóngtái sāncéng 崇臺三層 or “linked performance stage" (lián xitái 連戲 臺) commissioned by the Emperor Qianlong 乾隆 (1736-96) (Figure 1). ${ }^{3}$ Its exquisite exterior architecture and majestic interior décor synthesized traditional Chinese

\footnotetext{
${ }^{2}$ This three-tiered stage is situated in a palatial compound of the outer perimeter of the northeastern quadrant of the Forbidden City (now known as “the old palace” Gì Gōng 故宮), named the "Palace of Living Out My Years in Peace” (Níngshòu Gōng 寧壽宮), which was a place where Emperor Qianlong intended to celebrate his sixtieth birthday and to which he would be able to retire after abdication. Commissioned by Qianlong, construction was begun on this three-tiered stage in the thirty-sixth year of his reign (1771) and finished in the fortyfirst year (1776). It was renovated later in 1802 and again in 1891.

${ }^{3}$ One was a three-tiered stage built in the Longevity Peaceful Palace (Shòu'ān Gōng 壽安 宮); another was a three-tiered stage in the Mutual Pleasure Garden (Tónglè Yuán 同樂園) in the Old Summer Palace Yuánmíng Yuán 圓明 園; the other was the three-tiered stage the Clear Sound Pavilion (Qīngyīn Gé 清音閣) built in the Fortune Longevity Garden (Fúshòu Yuán 福壽 園) in the Jehol Summer Palace (Rèhé Xínggōng 熱河行宮).
} 
architecture and an elite representation of court theater during the Qing era. ${ }^{4}$ However, one might wonder how a three-tiered stage like the Pleasant Sound Pavilion was brought to life. I would argue that the threetiered stage was both a product of the confluence of economic prosperity and technological advance during the reign of Qianlong, as well as the result of Qianlong's personal desire. It was a synthesis of highly developed traditional Chinese architectural forms and innovations of Western theater, aided by advances in science in the Qing period. However, most importantly it stemmed from the Emperor Qianlong's personal passion for Chinese theater. The scope of this article will cover the Sino-Euro synthesis that engendered the architectural uniqueness of the Chinese three-tiered stage Pleasant Sound Pavilion.

\footnotetext{
${ }^{4}$ See my analysis of the exterior architecture and interior design of the three-tiered stage the Pleasant Sound Pavilion in "Marvel of the ThreeTiered Stage: the Pleasant Sound Pavilion" in Chinese Studies Journal, Faculty of Humanities, Kasetsart University, No. 1, April: 2006, pp. 185-218.
}

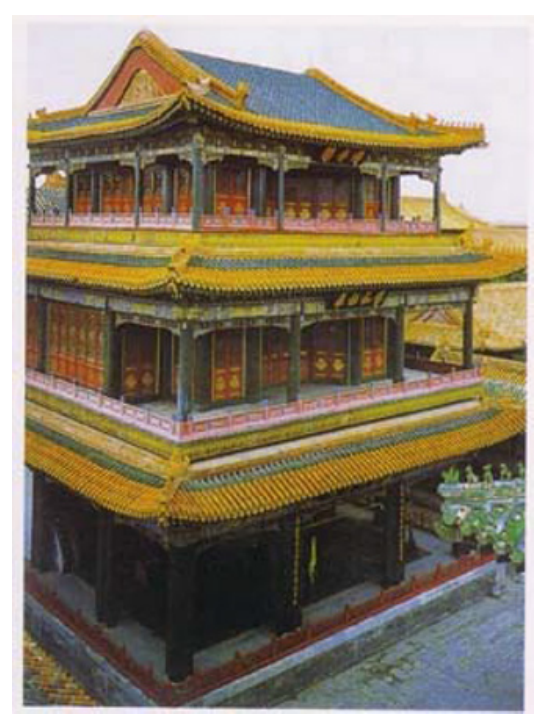

Figure1: Front view of the Pleasant Sound Pavilion three-tiered stage.

(Source: Lang Xiuhua, Zhōngguó Gŭdài Dìwáng yŭ Líyuán Shĭhuà, cover page)

\section{Traditional Chinese concept of monumentality}

Many Chinese scholars have argued that the marvel of the three-tiered stage stemmed from the prosperous economic conditions during the Qianlong period (Qiu 2000: 185). Others have pointed out that the innovative three-tiered stage is a result of the natural architectural development of multi-tiered buildings, which stems from a purely Chinese concept of "monumentality" (Chen 2001: 65). Wu Hung (1995: 4) has defined this notion of "monumentality" as that which "sustains such functions of a monument; a physical monument can survive even after it has lost its commemorative and instructive significance." The Chinese 
concept of "monumentality" thus denotes political, ethical, or religious obligations that perpetuate cultural memory and provide continuity to society. What I would like to highlight here is one aspect of "monumentality" in ancient Chinese architecture-its grandiosity.

To be sure, the grandiosity of ancient Chinese buildings can be traced back to the earliest times. Wang Guixiang (1985: 3) has suggested reasons why ancient Chinese people yearned for multi-storied buildings. $\mathrm{He}$ argued that such buildings have been a unique architectural form of China since ancient times. Wang claims that the ancient Chinese believed that heaven above was full of mystery. In addition, they believed that the depth of the sky symbolized the limitlessness of nature that they sincerely worshipped. Thus, such tall structures were an architectural instantiation of their desire to assimilate themselves to the natural environment, and a concrete object that situated humans between heaven and earth, representing a desire to reach into the mysteries of the heavens while staying, literally, grounded. In Wang's view architecture was the concrete parallel of early Chinese philosophy that attempted to place humans between heaven and earth, and within a constantly evolving natural environment.

Chinese architecture had been a highly developed, codified building system since earliest times. There were many multi-tiered structures that ancient Chinese people developed, indicating the Chinese concept of "monumentality." One has only to think, for instance, of the high platforms (tái 台) that were constructed since the Xià 夏, Shāng 商, and Zhōu 周 dynasties, the gate-tower (què 䦕) that stood at the entrance to metropolises and such multi-storied wooden constructions as the "Towering pavilion" (lóugé 樓閣), "Multi-tiered house" (chóngwū 重屋) and "Returning stream" (füliú 復溜) of the Han dynasty, or the pagoda of the Tang, Song and Yuan dynasties that stemmed from a synthesis between ancient Chinese architecture and central Asian architectural forms (Wang 1985: 3-6). As Wu Hung (1995: 102) has pointed out, the desire expressed in the construction of these tall buildings was that of the Chinese ruler's ambition for "political dominance over the whole nation, even foreign countriesseizing lands from other states, ruling the entire population, and becoming master of the world."

Multi-tiered architecture reached a new apex in the Qing dynasty, especially during the reign of Qianlong. Sun Dazhang (2002: 120) has argued that the Qing dynasty was the most vigorous period in Chinese architecture. There were, moreover, distinct innovations in style and expression. There was a greater monumentality, a greater use of brick and solid masonry, a greater simplicity and verticality in overall shape, and a greater symmetry and formality. That is to say, the traditional monumentality given by great size and simple parts was perpetuated, at least in the largest imperial palaces like the Forbidden City, the Yuanming Garden, and the Jehol Summer Palace in Chengde. These palaces consisted of various buildings constructed and designed in both traditional and innovative styles. As Laurence Sickman and Alexander Soper (1968: 464) have pointed out, "the observer's eye was attracted by decoration. So far as any 
chronological distinction may be drawn, one may say that decorative effects were still varied and ingenious under the Qing." Thus the architectural structure of the Qing period can be regarded, as Sickman and Soper have termed, "neo-classical respectability" (1968: 465). In other words, not only did Qing architecture adopt the recognizable styles of ancestral dynasties like the Han 漢, Tang 唐, Song 宋, Yuan 元 and Ming 明, but also modified such traditional styles and thus produced its own standard. For instance, compared to buildings constructed in the previous dynasties, those built in the Qing period were larger in scale and more vivid in their color scheme. Sickman and Soper (1968: 469) have argued "most monumental was the complex of audience courtyards and halls extending in a narrow, deep rectangular up the grand axis." Thus during the Qing dynasty, huge size was reinforced by an absolute symmetry, and the interplay between spaces and forms was made more dramatic by mounting heights. Moreover, color was extensively used to enhance the visual effect, as Sickman and Soper have pointed out, "from sumptuous dignity to playfulness; and though its use is as stereotyped as everything else, the conventions followed are bold and brilliantly successful" (1968: 465). Hence, compared to the multi-tiered architecture of previous dynasties, those built in the Qing, particularly in the reign of Qianlong, were more developed. This included the threetiered stage Pleasant Sound Pavilion.

Due to the number of construction and renovation projects initiated during his reign, Qianlong's rule has often been regarded as the golden age of Chinese architecture: 28 temples, 17 imperial garden and lodgings, and 25 theaters were built during the sixty years of Qianlong's reign (Fang 1984: 4754). Among them there are at least seven famous multi-tiered buildings. They are: the Pavilion of the Rain of Flowers (Yǔhua Gé 雨花閣 $)^{5}$ (Figure 2), the Pavilion of Great Conveyance of the Universal Tranquility Monastery in Chengde (Chéngdé Pŭníng Sì Dàchéng Gé 承德普寧寺大乘閣) ${ }^{6}$ (Figure 3), the Pavilion of Buddhist Fragrance in the Summer Palace Yihe Garden (Yihé Yuán Fóxiāng Gé 頣和園佛香閣) $)^{7}$ (Figure 4), the Pavilion of Myriad Fortunes in the Eternal Harmony Palace (Yǒnghé Gōng Wànfú Gé 雍和宮萬福閣 $)^{8}$ (Figure 5), the Universal Salvation Hall in Peaceful Eternality Monastery (Ānyuăn Miào Pŭdù Diàn 安遠

\footnotetext{
${ }^{5}$ It is a building built specially within the Forbidden City for the practice of Lamaism. It has three stories, the ground floor being surrounded by a covered verandah, the columnheads of which are decorated with animal masks with additional coiled dragons on those of the upper two stories. The upper pavilion roof has four curving ridges, each bearing a gilt bronze dragon, and is surmounted by an elongated golden roof pommel at the apex (Sun 2002: 429). ${ }^{6}$ This building was built in the twentieth year of Qianlong's reign (1755). It is seven bays in width and five bays in depth, three stories in height, totally 39.16 meters (Sun 2002: 429). ${ }^{7}$ This building was built in the twenty-fifth year of Qianlong's reign (1760). It has three stories. It is 36.48 meters in height. It was destroyed by British troops in 1846 and renovated during the seventeenth year of Guangxu's reign (1891) (Sun 2002: 429).

${ }^{8}$ This building was built in the ninth year of Qianlong's reign (1744). It is seven bays in width. It has two stories, totally 25 meters in height (Sun 2002: 429).
} 
廟普渡殿) ${ }^{9}$ (Figure 6), the Eminently Towering Grace Hall in the Sumeru Fortune Longevity Monastery (Xūmí Fúshòu zhī Miào Miàogāo Zhuāngyán Diàn 須彌福壽 之廟妙高庄嚴殿 ${ }^{10}$ (Figure 7), and most important of all, the three-tiered stage Pleasant Sound Pavilion in the Forbidden City.

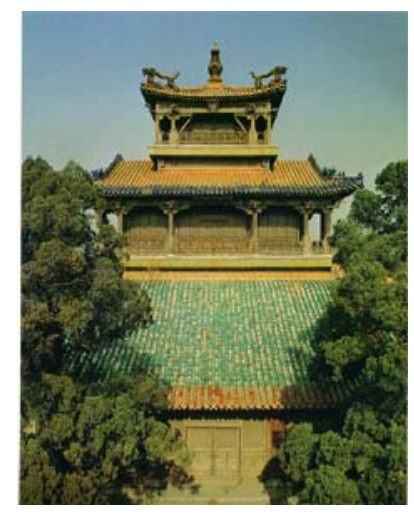

Figure 2: The Pavilion of the Rain of Flowers in the Forbidden City.

(Source: Zhang 2002: 143)

\footnotetext{
${ }^{9}$ This building was built in the twenty-ninth year of Qianlong's reign (1764). It is seven bays in width and seven bays in height. It has three stories, totally 26.50 meters in height (Sun 2002: 429-430).

${ }^{10}$ This building was built in the forty-fifth year of the Qianlong's reign (1780). It has five stories (Sun 2002: 430).
}

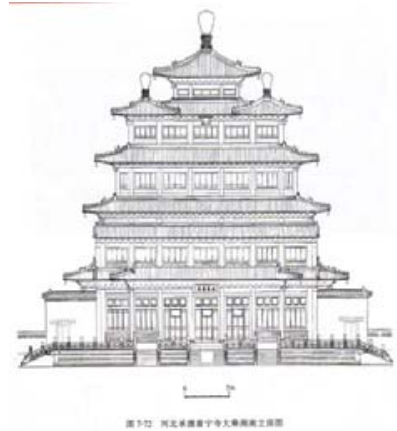

Figure 3: The Pavilion of Great Conveyance of the Universal Tranquility Monastery in Chengde.

(Source: Zhang 2002: 429)

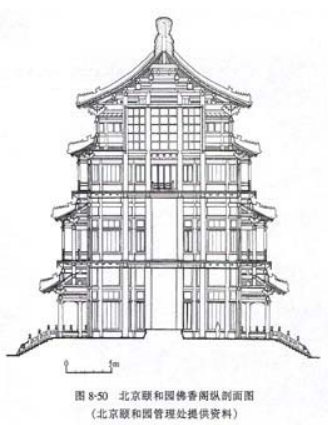

Figure 4: The Pavilion of Buddhist Fragrance of the Summer Palace Yihe Garden.

(Source: Zhang 2002: 429)

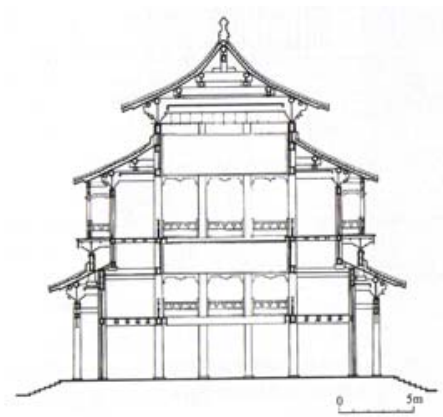

Figure 5: The Pavilion of Myriad Fortunes in the Eternal Harmony Palace.

(Source: Zhang 2002: 429) 


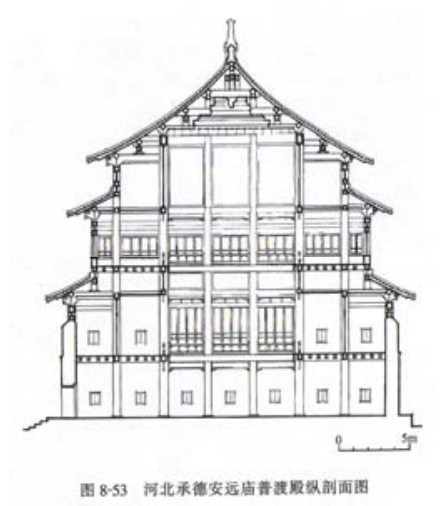

Figure 6: The Universal Salvation Hall in the Peaceful Eternality Monastery.

(Source: Zhang 2002: 430)

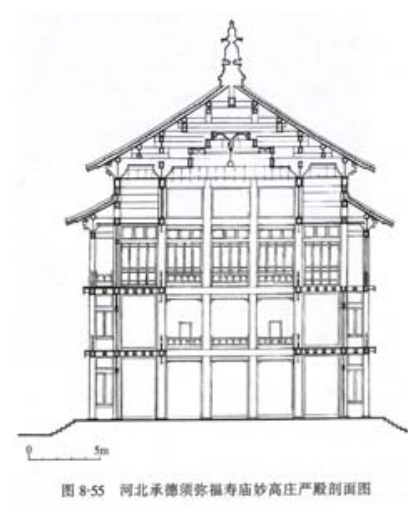

Figure 7: The Eminently Towering Grace Hall in the Sumeru Fortune Longevity Monastery.

(Source: Zhang 2002: 430)

This monumentality had an effect on the visual presentation of the grand theater as well. Zhao Yang (2001: 24) has argued that the Pleasant Sound Pavilion with its threetiered stage was one of the most massive and towering buildings in the Forbidden City. This three-tiered stage reflects the social as well as aesthetic emphasis of Chinese architecture, in that its monumentality fully expresses the power and prestige of the government and the monarch, the Emperor Qianlong. Consequently, as a venue for court entertainment, the Pleasant Sound Pavilion became a potent symbol of political power, and as such contributed to a new conception and symbolic representation of authority, through the form of "monumental architecture." To be sure, the desire for powerful architectural symbols differentiated such buildings as this theater from ordinary Chinese architecture; they had to be "unique" not only in material but also in scale of size and proportion.

\section{Western influence on Chinese three-tiered stage}

Nonetheless, the three-tiered stage Pleasant Sound Pavilion would not have had its present shape if Qianlong had not combined the architecture of Western theater with the monumentality of Chinese architecture. Among the major features of the Pleasant Sound Pavilion are the five handspike windlasses (lùlù 轆轤) or "lifting machines" installed backstage on the Fortune Stage (Fú Tái 福台) (Figure 8). ${ }^{11}$ I would argue that an adaptation of the machine room was derived from the shape of Western theaters during the Renaissance and Baroque periods. Like their Chinese counterparts, Renaissance and Baroque European theaters were known for their grandiose size. The Renaissance and

\footnotetext{
${ }^{11}$ The Fortune Stage is the top floor (third floor) of Chinese three-tiered stage. This machine primarily consists of series of winches (jiăochē 絞車), railings (lángān 欄杆), wheels (huálún 滑 輪) and ropes.
} 
Baroque theaters achieved a radically different shape, as the stage became framed by a permanent proscenium arch, visually separating the stage from the audience. The Renaissance and Baroque styles of theatrical decoration that were to become common across most of Europe had begun in Italy, the Italian style and technique would become the standard that nearly all other countries would emulate as secular theatrical performance spread across Europe. Theatrical performances in European countries like Italy and England during the Renaissance and Baroque were primarily a continuation of medieval traditions. They included a rich spectacle of tournaments, street pageants, and miracle plays, and the tradition remained vital until nearly the sixteenth century. Other spectacular productions, celebrating royal weddings, coronations, royal entries, and other significant moments of the monarch's reign, also were common, just as in the Qianlong period of China (Mulryne and Shewring 1991: 8-9).

Due to highly developed stage props like perspective scenery, large theaters were necessary to hold a plethora of background scenery. Such grand theaters were complex. They were composed of several functional rooms such as the scene room, the dressing room, a painter's room, multi-tiered galleries, several stairways, bridges, saloons, and machine rooms in upper and lower floors. Figure 9 and Figure 10 illustrate the reconstructions of the interior architecture of the Second Globe Theater built in 1614 and the Theater Royale built in 1711, respectively. Each figure shows a machine room providing space for a grid from which might hang a variety of painted cloths or scenes, mainly in the form of clouds which could accompany the descending throne (Mulryne and Shewring 1991: 88). As Mulryne and Shrewing (1991: 88) have pointed out, "it has been assumed that theatrical props and sceneries would descend through slots contrived in the heavens painted on the underside of the machine room floor, the openings being filled by hinged flaps when not in use. The use in this manner of the area of the machine room directly above the stage would still leave considerable space behind for the storage of scenes and properties, which could easily be lowered to stage level when their use was required."

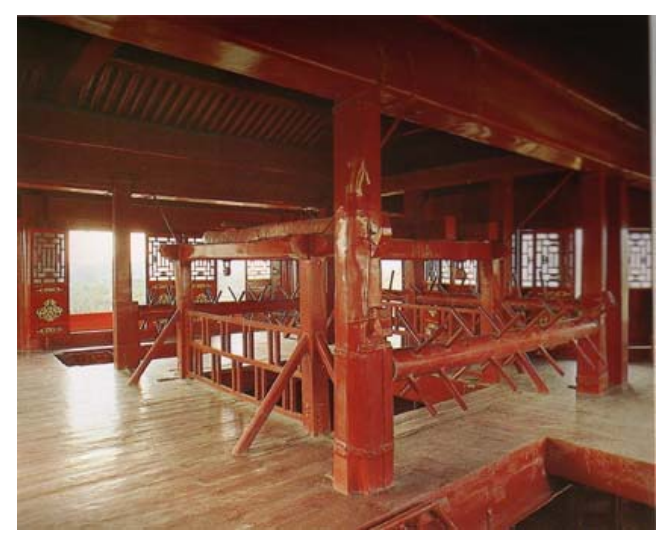

Figure 8: Five handspike windlasses for the lifting apparatus located in the backstage of the Fortune Stage of the Pleasant Sound Pavilion.

(Source: Yu Zhuoyun, Züjìn Chéng Gōngdiàn, p. 166, plate 184) 


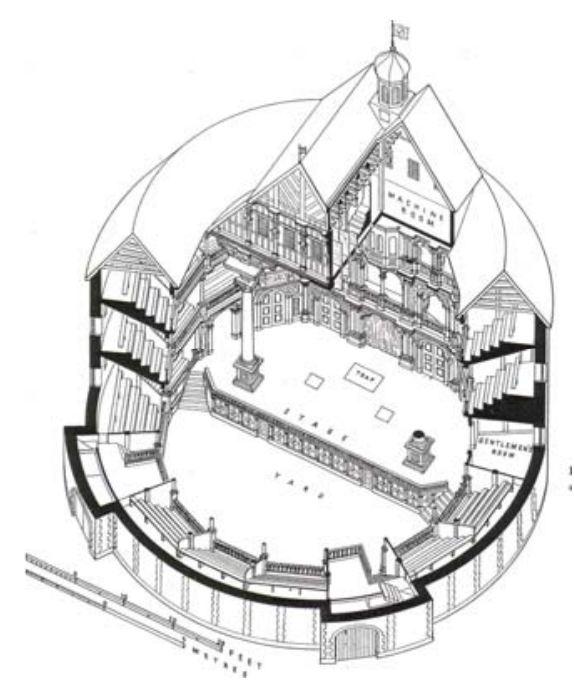

Figure 9: Reconstruction of the Second Globe Theater.

(Source: Mulryne 1991: 88)

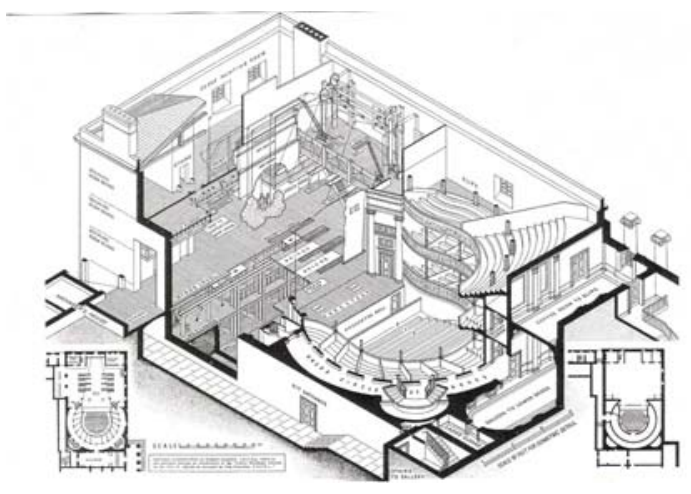

Figure 10: Reconstruction of the Theater Royale. (Source: Mulryne 1991: 89)

Given the absolute lack of such mechanical devices in the traditional Chinese theater, it seems obvious that Qianlong adapted this idea from contemporary European theater. Like the machine room in the Renaissance and Baroque Western theaters, the machine room built on the Fortune Stage controlled the design of the stage in plan and section, or not only did it function as a place for storing stage machinery, but it also necessitated a triple number of the theater. It thus formed an integral part of the structure of the grand theater. Such a machine room accommodated and facilitated the complexity of court performances. Without it, many of the spectacular scenes of the long court plays would have been impossible.

There are clear similarities between the machine rooms of Western theater and the "lifting machine" of the Chinese three-tiered stage. Edward Carrick (1931: 9) has explained that stage machines of the Western theater during the Renaissance and Baroque periods were used to move the hands and eyes of the great figures of gods. These machines were brought to great perfection by the requirements of the Renaissance and Baroque drama performances. As a result, the best architects of the time were called upon to design the costumes and invent the machines, or "ingeni" as they were called, by which angels and cherubs could rise and descend to and from a material heaven portrayed on stage. The first such machine, known as "Paradiso," was designed by a well-known Italian architect, Filippo Brunelleschi (13771446), around 1400 (Figure 11). Other Italian architects like Il Cecco invented engines on a grander scale that powered many angels and gods, all moving together, which required a tremendous number of ropes and pulleys and cloud cotton wool to hide them (Figure 12). Aristotle da San Gallo invented prism scenery (Figure 13); Baldassare Peruzzi invented perspective scenes; and Inigo Jones, an English architect, painter, stage and costume designer, brought 
the Italian technique of perspective scenery to the English theater (Carrick 1931: 9-16).

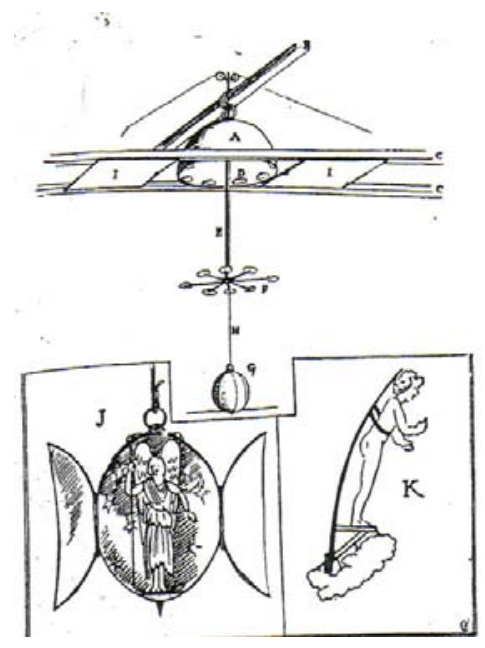

Figure 11: A machine called "Paradiso" invented by Filippo Brunelleschi. (Source: Carrick 1931: 10)

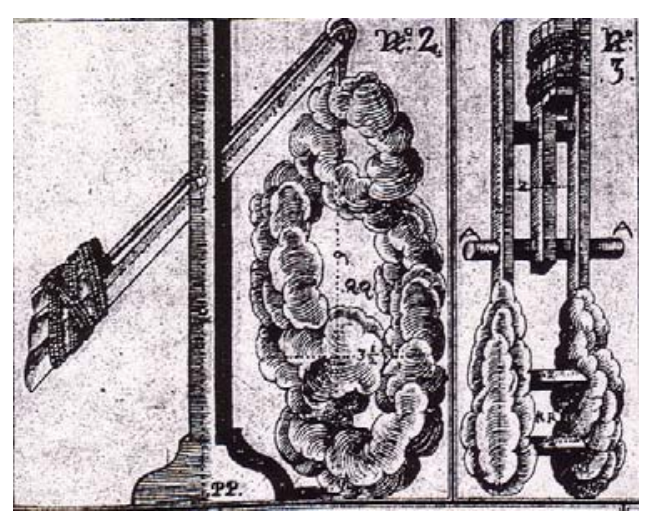

Figure 12: A stage machine consisting of pulleys and ropes, which were hidden by cloud cotton wool, invented by Il Cecco. (Source: Carrick 1931: 10)

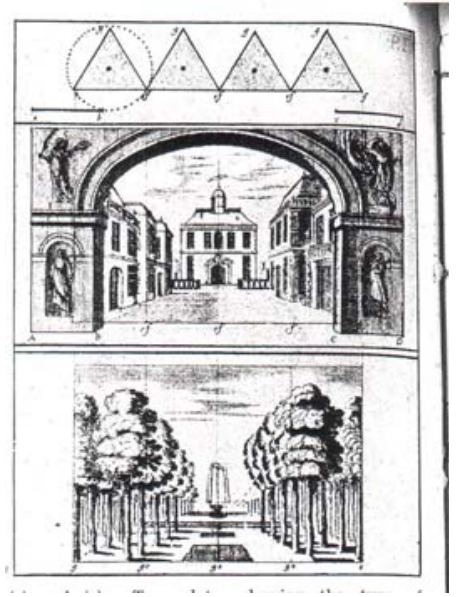

Figure 13: A prism stage scenery invented by Aristotle da San Gallo.

(Source: Carrick 1931: 11)

The application of mechanical technology accounts to a large extent for the innovation of the Chinese three-tiered stage. Five handspike windlasses were installed backstage on the Fortune Stage of the Pleasant Sound Pavilion. These windlasses and pulleys were quite traditional and, according to Joseph Needham (1965: 95), were a usual feature of hydraulic technology in China from very early times. He has also noted that pulleys were also employed in court entertainments. For example, in the Rúlín Gōngyì 儒林公議 [Public-Spirited Sayings of Confucian Scholars], there is a record that a group of two hundred and twenty female dancers was hauled up an incline from a lake in boats in 915 A.D. (Needham 1965: 96).

However, the application of pulleys, handspike windlasses, ropes and wheels used to convert rotary motion by tripping and for applying the tractive power of men, according to Needham, might have derived 
from Western technology, particularly from the Jesuits, who came to China during the fifteenth century (Needham 1965: 221). There were three significant engineering books produced in the early years of the seventeenth century: the Táixī Shuĭfă 台西 水法 [Hydraulic Machinery of the West] written in 1612 by Sabatino de Ursis and Xu Guangji 徐光吉, the Qijī Túshuo 奇機圖說 [Diagrams and Explanations of Wonderful Machines] written in 1627 by Johann Schreck and Wang Zheng 王正, and the Shùj̄i Túshuō 數機圖 說 [Diagrams and Explanations of a Number of Machines] written by Wang Zheng 王正 (Needham 1965: 221). An interesting point in the section on Tái Gēng 台耕 or "mechanical ploughing" recorded in the Qiji Túshuō is an illustration of a mechanical plough showing handspike windlasses in use for drawing the plough back and forth across the field (Figure 14). According to Needham, such a mechanical technique was imitated from the European windlass invented by Weimer (1430) and Besson (1578) (Needham, 1965: 218). This early handspike windlass provided an easy model to emulate when creating machinery for three-tiered stages like the Pleasant Sound Pavilion.

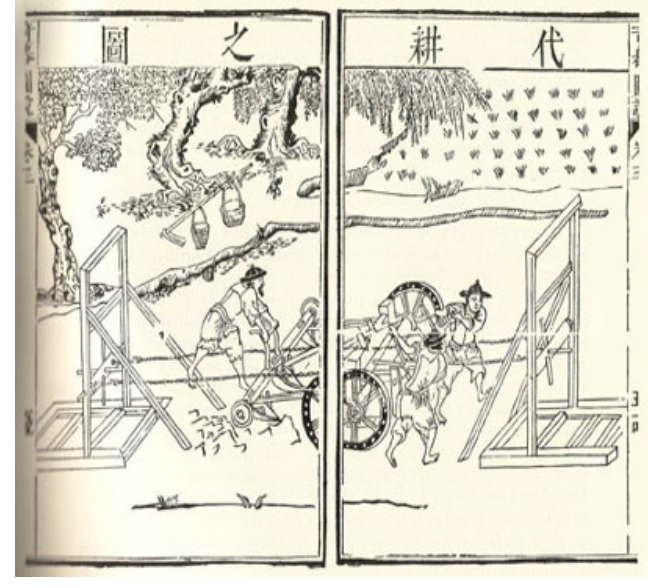

Figure 14: A mechanical plough showing handspike windlasses in use for drawing the plough back and forth across the field, probably influenced by Western technology. (Source: Needham 1965: 218)

Another interesting technology that was adapted for the Chinese three-tiered stage is water-raising machinery. As I have mentioned earlier, one large water well was installed underneath the Pleasant Sound Pavilion. Needham has pointed out that such a fundamental type of water-raising machine existed in China since early times (Needham 1965: 335). Although the actual waterraising technique is originally Chinese, I believe that the concept of sprinkling water on to the stage must have been adopted from the water fountain of Western technology. To be sure, the Emperor Qianlong has been known for his predilection for such technology as the water fountain, which was an ancient Western pleasure that became very popular in seventeenth-century Italy and France. As Jin Yufeng has pointed out Qianlong's project of constructing a Western-style palatial garden in the Yuanming Garden was originally inspired 
by his fondness for exotic European fountains whose pictures were presumably shown him by certain Jesuits who were invited to the Qing court. Thus, it is possible that the Italian and French Jesuits at the Qianlong court tried to impress the emperor with great Western fountains. There are records indicating that the European-style water fountain project in the Yuanming Garden was successfully completed thanks to the collaboration between Giuseppe Castiglione (1688-1766), an Italian Jesuit artist, and Father Michel Benoit (17151774), a French Jesuit mathematician and engineer (Jin 1984: 21-24). ${ }^{12}$

The idea of sprinkling water as artificial rain became one of the special theatrical effects of the Pleasant Sound Pavilion. The well which was located under the stage functioned as the source of sprinkled water during the drama performance. To sprinkle water, a pipe, which was fastened to a rope, was lifted up above the stage by revolving pulleys from whence it could spurt on to the Longevity Stage. The well also had a significant function to help produce sound effects during court drama performances. $\mathrm{Yu}$ Jian (2003: 448) has noted that water spurting equipment could be installed in the

\footnotetext{
${ }^{12}$ There were numerous water fountains built during Qianlong's reign in the Yuanming Garden. A large fountain in the main façade of the Calm Sea Hall (Hăiyàn Táng 海宴堂) spouted in the central pool, surrounded by twelve bronze animal heads, that spouted a stream of water to the pool one after the other every two hours. Another awe-inspiring water fountain was called the Great Fountains (Dà Shuĭfă 大水法), located further east of the Calm Sea Hall (Jin 1984: 2124).
}

dijing 地井 or "pit," "13 where it would be used to imitate and create the sound of water as a special effect. For instance, in the fourth act of the first volume of the Shéngping Băofá 升平寶筏 or The Precious Raft of Peaceful Times, ${ }^{14}$ entitled "Stone monkeys take possession of the waterfall" (Shi hóu'er qiángzhàn shuillián 石猴兒強佔水廉), it is the dijing that mainly creates the stage scenery by functioning as a "waterfall cave" (Shuülián Dòng 水廉洞). The stage direction notes that to be able to create authentic scenery, "at least four buckets of water (from the well) have to be prepared for this act." (Cǔchū yùbèi sì shuütŏng cáigòu 此出 預備四水桶才夠。) (Shéngping Băofá 1965: 10 a. -10 b.).

There are some similarities between the application and function of stage machinery in the Western theater during the Renaissance and Baroque periods and the Chinese three-tiered stage. That is to say, such stage machinery allowed for the mobility of actors and props, and created spectacular scenes. . Here is a description of a performance in the Western theater during the fifteenth century.

\footnotetext{
${ }^{13}$ Diǰng or "pit" was one of the stage props exclusively designed in the Chinese three-tiered stage. It functioned as a pathway that allowed the mobility of actors during the gala performances in this massive theater.

${ }^{14}$ This play is an adaptation play of the story The Journey to the West (Xīyóu $J i$ 西游記) which is a fantasy novel based on the real-life pilgrimage of a famous Chinese monk, Xuan Zang 玄牀 (596664) to India to bring back the sacred Buddhist scriptures during the Tang dynasty. It is one of the major court plays rewritten and adapted for on the three-tiered stage in the Qing dynasty.
} 
Then Mary appeared, under a portico supported by eight pillars and began to repeat some verses from the Prophets, and while she spoke, the sky opened, revealing a figure of God the Father, surrounded by a choir of angels. No support could be seen either for His feet or for those of the angels, and six other seraphs hovered in the air, suspended by chains. In the center of the group was the Archangel Gabriel, to whom God the Father addressed His words, and after receiving his orders, Gabriel descended with admirable artifice and stood, half-way in the air, at the same height as the organ. Then, all of a sudden, an infinite number of lights broke out at the foot of the angel choir, and hid them in a blaze of glory...At that moment the Angel Gabriel alighted on the ground, and the iron chain which he held was not seen, so that he seemed to float down on a cloud....

(Campbell 1873: 60)

Similar scenes also took place in the grand performances of the Chinese three-tiered stage. For instance, the first act of the first

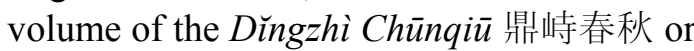
The Annals of the Three Kingdoms ${ }^{15}$ entitled "From the five-colored clouds a letter descends in order to manifest an auspicious omen," (Wǔsè yún jiàng shūchéng ruì 五色 雲降書呈瑞) clearly demonstrates an

\footnotetext{
${ }^{15}$ It is an adaptation of the story of The Romance of the Three Kingdoms (Sānguó Yănyì 三國演義 ). It is one of the major court plays adapted for the three-tiered stage in the Qing dynasty.
}

orderly arrangement of actors on the threetiered stage.

A group of actors costumed as spirit officials enter from the Fortune Stage, the Prosperity Stage, and the Longevity Stage. They act out dancing. And then they exit.

A group of actors costumed as Eighteen Indian Arhats ${ }^{16}$ and Cloud Envoys enter the Longevity Stage. Dragons descend from the cloud sack. ${ }^{17}$ Tigers enter from the dijing. All characters act out dancing together.

On the Longevity Stage, in front of the Immortal Tower hangs a large screen, on which portraits of Western Ocean Bodhisattva of Foreign Mien, Gaté ${ }^{18}$ and Heavenly $\mathrm{Kings}^{19}$ are depicted.

A group of actors costumed as Eight Heavenly Dragons ${ }^{20}$ enter from the Fortune Stage.

A group of actors costumed as bodhisattvas, Sakyamuni, ${ }^{21}$ enter from the Prosperity Stage.

\footnotetext{
${ }^{16}$ They are eighteen Buddhists who have attained nirvana.

${ }^{17}$ A cloud sack (yúndŏu 雲兒) is a kind of theatrical prop specially designed to assist the mobility of actors on the three-tiered stage. ${ }^{18}$ Jiédi 揭帝 or Jiédi 揭諦 is one of the wellknown protective spirits in Buddhism.

${ }^{19}$ Heavenly kings are regarded as protective spirits in different realms of Buddhist heaven.

${ }^{20}$ They are the eight protecting spirits of Buddhism.

${ }^{21}$ Sakyamuni is the sage of the Sakyas, a Buddhist-Lamaist god. He is the historical Buddha whose color is golden and where attribute is a bowl.
} 
Several actors costumed as Bhiksuni, ${ }^{22}$ Four Great Bhodisattavas, and young acolytes enter from the Immortal Tower.

A group of actors costumed as Heavenly Kings enter from the Longevity Stage.

衆扮靈官從福台、祿台、壽台 上，跳舞科，下。

衆扮十八天笲羅漢、雲使上壽 台, 龍從雲兒下, 虎從地井上, 合舞科。

壽台場上仙樓前挂大西洋番像佛 菩薩、揭帝、天王等畫像帳幔一 分。

衆扮八部天龍從福台上。

衆扮菩薩、阿難迦旪、佛從祿台 上。

衆扮比丘尼、四大菩薩、童子從 仙樓上。

衆扮天王從壽台上。

(Dǐngzhì Chūnqiū 1965: 3 a.-4 b.)

Thus we can see that such celestial scenes filled with deities, angels, and gods in both Western theater and on the Chinese threetiered stage alike create a material representation of heaven for their audiences. With its complicated machinery above and below the stages, the Pleasant Sound Pavilion was able to enrich the visuality of drama with innumerable scenic exhibitions. Like its Western counterpart, with its mezzanine floor, traps, pits, hidden bridges, and other complicated mechanisms, the three-tiered stage was not merely a place for acting but an enormous box of tricks.

${ }^{22}$ Bhiksuni is a term a female Buddhist disciple.
Not only was the Western idea of the water fountain imitated to create special effects on the Chinese three-tiered stage, but other Western theatrical props were also adapted to enhance performance strategies in this grand theater. One of the most interesting Chinese props that might have been adapted from Western theatrical props is a prop called the“sea turtle" (áo yú 鰲魚) (Figure 15). In the grand play entitled the Luóhàn Dùhăi 羅漢渡海 [Arhats Crossing the Ocean], a sizable theatrical prop in the shape of a sea turtle plays a significant role. This prop could contain more than ten people and had a mechanical pipe installed inside that sucked water from the water well and spurted it out of the sea turtle's mouth. Cao Xinquan 曹心泉 recorded in his Qián Qīng Nèitíng Yănxì Huíyì Lù 前清内廷演戲回憶 錄 [Memoir of Court Performance in the Early Qing Period]:

(3) Arhats Crossing the Ocean." This play employs one theatrical prop shaped like a huge sea turtle whose inside can contain more than ten people. By using a mechanical pipe to suck up water from the well it can spurt out water from the sea turtle's mouth.

三, 《羅漢渡海》, 有大切末制成 之鰲魚, 内可藏數十人, 以機筒從 井里吸水, 由鰲魚口中噴出。

(Yu 2003: 451) 


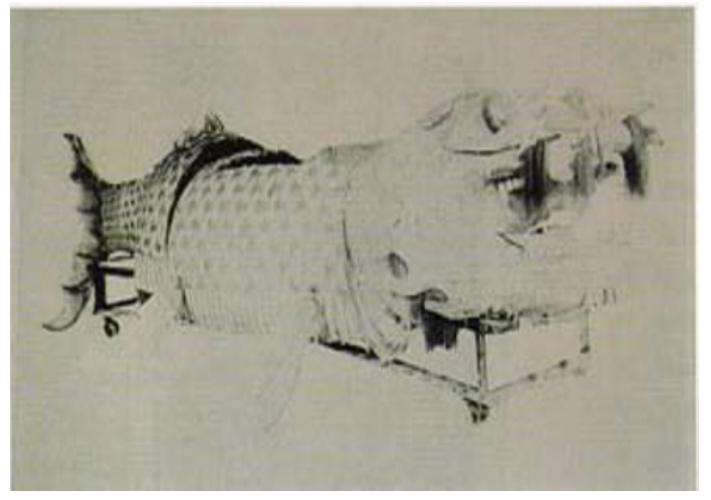

Figure 15: A prop called "sea turtle" employed on the Chinese three-tiered stage. (Source: Zhao 2001: 16)

It is highly probable that this theatrical prop was designed in imitation of a Western theatrical prop called the "sea monster" (Figure 16). This sea monster prop was invented by an Italian architect named Giutti in the fifteenth century (Carrick 1931: 14). In this figure we can see that the sea monster consisted of a monster fish made of canvas and wood, covered with tin and painted; a small boat upon which the sea monster was mounted; a hole cut through the boat to sprinkle water, and a man who controlled the movement of the sea monster. One can certainly conjecture that the sea turtle employed on the Chinese three-tiered stage was probably an imitation of the sea monster prop of Western theater.

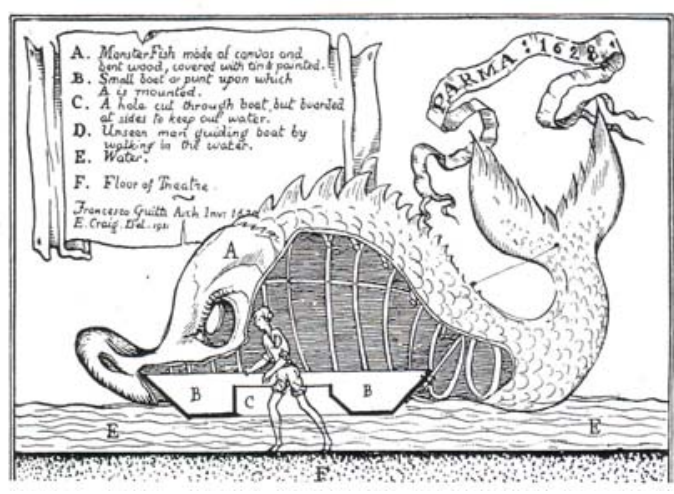

Figure 16: A prop called "sea monster" invented by an Italian architect named Giutti in the fifteenth century.

(Source: Carrick 1931: 14)

\section{Emperor Qianlong's passion for Chinese drama and Western arts}

In my opinion, however, the most significant factor that brought the Chinese three-tiered stage to life was Emperor Qianlong's passion for and patronizing of Chinese drama. It was recorded that in his youth the emperor wrote a one-act, one-character play (Dújiăo Xi 獨角戲) called A Beggar Picks Up Gold (Huāzi shijinn 花子拾金) and sang for his mother on each of her birthdays (Qiu, 2000: 194). He also used to perform on the small theatrical stage named the Elegance Remains Always (Fēng Yă Cún 風雅存 $)^{23}$ in

\footnotetext{
${ }^{23}$ This is a small in-court theatrical stage built in the back hall on the western side of the Imbibed Fragrance Studio under Qianlong's commission. The whole stage is made of wood. Its platform is 0.5 meters in height; the entire stage is 3.9 meters in width, 3.5 meters in depth, and 2.2 meters in height. This in-court stage was designed for emperors and empresses watching short drama performances after their meals.
} 
the Imbibed Fragrance Studio (Shüfāng Zhāi 漱芳齋). ${ }^{24}$ Furthermore, it was recorded that he used to sing a few dramatic songs in the Retiring from Hard Work Studio (Juănqin Zhāi 倦勤齋) in the Palace of Living Out My Years in Peace (Zhou 1975: 499). Moreover, he once entertained his mother on her birthday by playing a solo role of the aged Laizi 徠子 (Qiu 2000: 195). ${ }^{25}$

Furthermore, Qianlong's personal interest in Western architecture and art formed an integral part in the construction of the massive three-tiered stage. This seems to be a general interest, which can also be seen in his use of western architecture and art in the Yuanming Garden: the Symmetric and Amazing Pleasure (Xièqi Qù 諧奇趣), the Entrance of the Flower Garden (Huāyuán Mén 花園門), the Maze (Mi Gōng 迷宮), the Calm Sea Hall, the Square Outlook (Fāngwài Guān 方外觀), the Great Fountain, and the Great View of the Distant Seas (Yuănyíng Guān 遠瀛觀). Besides westernstyle architecture, Emperor Qianlong was also fond of Western-style paintings by court artist Giuseppe Castiglione and mechanical gadgets like European clocks (Figure 17) and equatorial armillary spheres (Figure 18). Beyond a doubt, Qianlong was the first Chinese ruler to accommodate any

\footnotetext{
${ }^{24}$ See the study on the in-court stage in the Imbibed Fragrance Studio in Gù Gōng

Zhoukān 故宫周刊 [Weekly Journal of the Forbidden City], No. 127, Vol. 8, pp. 35-42.

${ }^{25}$ Laizi is regarded as one of the twenty-four examples of children's filial love for their parents. There was a record that Laizi, at the age of eighty, made his parents forget their great age by behaving towards them as if he were still a little child (Qiu 2000: 195).
}

substantial European architecture in an imperial palace.

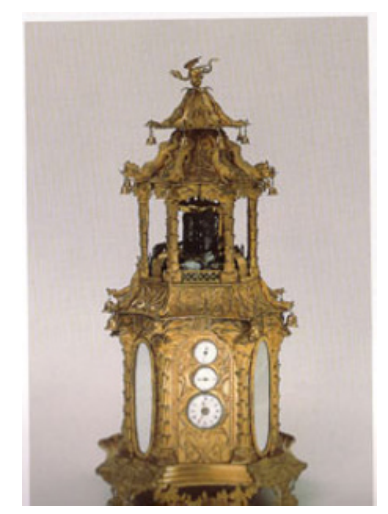

Figure 17: Spring-operated clock in the shape of a pavilion with Chinese and European design produced during the reign of Qianlong.

(Source: Zhang 2002: 118)

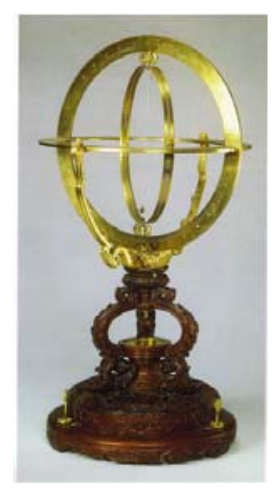

Figure 18: An equatorial armillary sphere with Chinese and European design produced during the reign of Qianlong.

(Source: Zhang 2001: 129) 


\section{Conclusion}

We can see from the above that the threetiered stage as represented by the Pavilion of Pleasant Sound was a synthesis of traditional concepts of monumentality and Western architecture, art, and technology. Clearly, architects, painters, designers, managers, effects specialists, and even the Emperor Qianlong himself adapted their knowledge to the three-tiered stage. The overall design of the three-tiered stage Pleasant Sound Pavilion creatively intermarried Chinese views of entertainment and life, artistic craftsmanship, and aesthetic taste, with Western architectural and theatrical techniques. In some ways, it can be seen that the Pleasant Sound Pavilion, both as a traditional monument and as a representation of global synthesis, provides a fitting symbol for the paramount status of the Emperor Qianlong, who governed over a vast, multiethnic empire.

\section{References}

Cao Xinquan 曹心泉. 1933. “Qián Qīng nèitíng yănxì huíyì lù 前清内廷演回錄” [Memoir of Court Performance in the Early Qing Period].Jùxué Yuèkān 劇學刊 [Monthly Journal of Study on Drama]. Ser. 4, Vol. 2. (April): 21-29.

Campbell, Lily B. 1873. Scenes and Machines on the English Stage during the Renaissance. New York: Barnes and Nobel.

Carrick, Edward. 1931. "Theater machines in Italy, 1400-1800." Architecture Review. (August): 9-16, 34-36.
Chen Fang 陳芳. 2001. Qiánlóng Shíq $\bar{\imath}$ Běijīng Jùtán Yánjiū 乾隆時期北京 壇研究 [Study of Theatrical Hall in Beijing during the Qianlong Period]. Beijing: Wenhua yishu chubanshe.

Dingzhi Chūnqiū 鼎峙春秋 [The Annals of the Three Kingdoms]. 1964. Gǔběn Xiqǔ Cōngkān 古本戲曲叢刊 [Collection of Ancient Drama]. Ser. 9, No.3. Shanghai: Zhonghua shuju.

Fang Xianfu 訪咸孚. 1984. “Qiánlóng shíqī de jiànzhù huódòng yǔ chéngjiù 乾隆時 期的建築活動與成就” [Architectural Activities and their Success during the Qianlong Reign]. Gǔjiàn Yuánlín Jishù 古建園林技術 [Journal of Traditional Architecture and Gardens]. No.2. (December): 47-54.

Jin Yufeng 金餘峰. 1984. “Yuánmíng Yuán xīyáng lóu píngxi 圓明園西洋樓本細” [A Critical Analysis of the European Section in the Yuanming Yuan]. Yuánming Yuán Xuékān 圓明園學刊 [The Yuanming Garden Journal]. Vol. 3: 21-34.

Mulryne, J. R. and Margaret Shewring (eds). 1991. Theater of the English and Italian Renaissance. New York: St. Martin Press.

Needham, Joseph. 1965. Science and Civilization in China. Vol. 4. Cambridge: Cambridge University Press. 
Niu Chuanhai 牛川海. 1977. Qiánlóng Shi Jùchăng Huódòng Zhī Yánjiū 乾隆時劇 場活動之研究 [Research on Theatrical Activities during Qianlong's Reign]. Taibei: Huagang chubanshe.

Petcharapiruch, Sasiporn. 2006. "Marvel of the Three-Tiered Stage: the Pleasant Sound Pavilion." Chinese Studies Journal. Faculty of Humanities, Kasetsart University, No. 1. (April): 185-218.

Qiu Huiying 丘慧瑩. 2000. Qiánlóng Shíqi Xiqǔ Huódòng Yánjiū 乾隆時期戲曲活 動研究 [Study of Dramatic Activities during the Reign of Qianlong]. Wenjin chubanshe.

Shéngping Băofá 升平寶笺 [The Precious Raft of the Peaceful Times]. 1964. Gǔběn Xìǔ Cōngkān 古本戲曲叢刊 [Collection of Ancient Drama]. Ser. 9, No.4. Shanghai: Zhonghua shuju.

Sickman, Laurence and Soper, Alexander. 1968. The Art and Architecture of China. New Haven and London: Yale University Press.

Sun Dazhang 孫大章. 2002. "Qìngdài jiànzhù 清代建築” [Architecture in the Qing Dynasty]. In Zhōngguó Gǔdài Jiànzhù Shř 中國古代建築史 [History of Ancient Chinese Architecture]. Vol. 5. Beijing: Beijing wenmin chubanshe.

Wang Guixiang 王貴祥. 1985. “Luèlún Zhōngguó gǔdài gāocéng mùgòu jiànzhù de fāzhăn 略論中國古代高層
木構建築的發展” [Summarized

Discussion on Development of Ancient Chinese Wooden Architecture]. Gǔjiàn Yuánlín Jishù 古建園林技術 [Journal of Traditional Architecture and Gardens]. No. 2 (March): 3-15.

Wu Hung. 1995. Monumentality in Early Chinese Art and Architecture. Stanford: Stanford University Press.

Yu Jian 俞健. 2003. “Qinggōng dà xitái yǔ wǔtái jishù 清宮大戲臺與舞臺技術 [Grand Theater of the Qing Court and Its Theatrical Techniques]." Zhou Huabin 周 華斌 and Zhu Lianqun 朱聯群 (eds.), Zhōngguó Jùchăng Shìlùn 中國劇場史論 [Discussion on History of Chinese Theater], Vol. 2. pp. 440-458. Beijing: Beijing Guangbo xueyuan chuban she.

Zhao Yang 趙楊. 2001. Qīngdài Gōngtíng Yănxì 清代宮廷演戲 [Court Drama in the Qing Dynasty]. Beijing: Zijin cheng chubanshe.

Zhou Yibai 周贻白. 1975. Zhōngguó Xìjù Fāzhăn Shĭ 中國戲劇發展史 [History of Development of Chinese Drama]. Tainan: Minmian chubanshe.

Zhang Hongxing 張宏性. 2002. The Emperor Qianlong: Treasures from the Forbidden City. Edinburgh: National Museums of Scotland. 